\title{
RANCANG BANGUN APLIKASI PENDAFTARAN YUDISIUM PADA FAKULTAS TEKNIK UNIVERSITAS TEKNOLOGI SUMBAWA BERBASIS WEB
}

\author{
Neva Nurliana ${ }^{1}$, Shinta Esabella ${ }^{2}$ \\ ${ }^{1,2}$ Teknik Informaika, Universitas Teknologi Sumbawa \\ email: shinta.esabella@uts.ac.id
}

\begin{abstract}
Abstraksi: Penelitian ini bertujuan untuk (1) untuk proses pendaftaran yudisium dalam kelayakan berkas yang telah diajukan oleh mahasiswa, (2) dapat memudahkan pihak administrasi Fakultas Teknik dalam mengecek dan menyetujui berkas-berkas yang telah diberikan oleh mahasiswa sebagai syarat untuk melakukan yudisium. Penelitian ini menggunakan metode pengembangan perangkat lunak spiral dan dibangun dengan menggunakan dibangun dengan menggunakan bahasa pemrograman PHP, dengan Database MySQL dan Text Editor SublimeText. Metode pengumpulan data mengggunakan observasi, wawancara, studi pustaka dokumentasi, dan menggunakan metode pengujian Alpha Test yaitu pengujian yang dilakukan terhadap aplikasi untuk memastikan bahwa aplikasi dapat berjalan dengan benar sesuai dengan kebutuhan dan tujuan yang diharapkan. Hasil dari penelitian yaitu Aplikasi Pendaftaran Yudisium Berbasis Web yang terdapat data mahasiswa, data prodi, data akun, data event, dan data feedback.
\end{abstract}

Kata Kunci. Aplikasi, Web, Alpha Test dan Spiral.

\begin{abstract}
This study aims to (1) for the process of registering the judiciary in the eligibility of the files that have been submitted by students, (2) can facilitate the administration of the Faculty of Engineering in checking and approving the documents that have been given by students as a condition for doing the graduation. This research uses a spiral software development method and is built using built using the PHP programming language, with MYSQL Database and SublimeText Text Editor. Data collection methods use observation, interviews, document library studies, and use the Alpha Test test method, which is a test conducted on the application to ensure that the application can run correctly in accordance with the needs and objectives expected. The results of the study are Web Based Judisium Registration Application which contains student data, study program data, account data, event data, and feedback data.
\end{abstract}

Keywords. Application, Web, Alpha Test and Spiral.

\section{PENDAHULUAN}

\subsection{Latar Belakang}

Pada UTS terdapat bagian administrasi di Fakultas Teknik, sehingga mahasiswa dapat melakukan pendaftaran yudisium yang dimana terdapat proses kelayakan berkas yudisium sebagai syarat agar mahasiswa dapat melakukan yudisiumnya.Yudisium merupakan proses menyangkut penerapan nilai dan kelulusan mahasiswa dari seluruh proses akademik yang telah dijalaninya selama perkuliahan. Dalam hal ini berkas yudisium yang diurus oleh pihak Fakultas Teknik khususnya di bagian administrasi yaitu dalam proses mengecek dan menyetujui berkasberkas yang telah dikumpulkan sesuai dengan syarat dan ketentuan oleh mahasiswa masih dilakukan secara manual, seperti saat ini nama mahasiswa yang akan melakukan yudisium, dan dalam mengecek lembaran atau kelengkapan berkas satu persatu sehingga membutuhkan waktu yang lama untuk proses pemeriksaan lembaran berkas yang telah dikumpulkan. Terkadang ada berkas yang hilang dan dapat mengakibatkan keamanan berkas tidak terjaga. Seperti yang disampikan oleh Kepala Tata Usaha Fakultas Teknik, Bapak Hery Krisna Hermawan dalam hasil wawancara yang penulis lakukan, beliau menyampaikan keinginan adanya aplikasi khususnya pendaftaran yudisium untuk memudahkan pihak administrasi Fakultas Teknik dalam proses pengecekan berkas yudisium sehingga mahasiswa layak untuk mengikuti yudisium.

Berdasarkan masalah yang telah dipaparkan di atas, penulis memanfaatkan teknologi berbasis web yaitu "Rancang Bangun Aplikasi Pendaftaran Yudisium pada Fakultas Teknik Universitas Teknologi Sumbawa Berbasis Web”. Diharapkan dengan adanya aplikasi ini dapat memudahkan proses pengurusan berkas yudisium bagi pihak administrasi Fakultas Teknik serta menjaga keamanan berkas. Serta memudahkan dalam pemeriksaan dan menyetujui semua berkas yang telah diberikan oleh mahasiswa dengan mudah dan cepat. Dalam Rancang Bangun Aplikasi Pendaftaran Yudisium pada Fakultas Teknik Universitas Teknologi Sumbawa berbasis web ini terdiri dari beberapa teori yang mendasar untuk mendukung pengerjaannya, adapun dasar teori tersebut adalah sebagai berikut : [1] Menurut Amin, 2016, Perancangan terstruktur adalah suatu pendekatan yang bekerja dari sudut pandang yang 
lebih tinggi menuju tingkat lebih rendah yang lebih rinci, dimana keinginan pemakai disajikan dalam diagram alir data. [2] Menurut Anhar,2010, Database adalah sekumpulan tabel-tabel yang berisi data dan merupakan kumpulan dari field atau kolom. Struktur file yang menyusun sebuah database adalah Data Record dan Field. [3] Sedangkan menurut Arief, 2011, MySQL adalah salah satu jenis database server yang sangat terkenal dan banyak digunakan untuk membangun aplikasi web yang menggunakan database sebagai sumber dan pengolahan datanya. [4] Menurut Buana, 2014, XAMPP adalah perangkat lunak open source yang diunggah secara geratis dan bisa dijalankan di semua operasi seperti windows, linux, solaris, dan mac. [5] Menurut Emzir, 2011, Kualitatif merupakan salah satu pendekatan yang secara primer menggunakan paradigma pengetahuan berdasarkan pandangan konstruktivisme atau pandangan partisipator atau keduanya dengan strategi pendekatan salah satunya adalah studi kasus untuk mengumpulkan data penting secara terbuka terutama dimaksudkan untuk mengembangkan tema-tema dari data. [6] Dan menurut Priyatna, 2013, Web adalah nama popular untuk world wide web (www), yakni suatu aplikasi internet yang terdiri dari perangkat lunak, kumpulan protokol, dan seperangkat aturan yang memungkinkan seseorang mengakses internet. [7] Menurut Kurniawan 2012, rancangan bangun aplikasi merupakan hasil analisa dalam bentuk perangkat lunak yang digunakan untuk menyelesaikan masalah-masalah dengan menciptakan atau memperbarui sistem menggunakan kemampuan komputer. [8] Sedangkan menurut Kustiyaningsih, 2011, Database adalah Struktur penyimpanan data untuk menambah, mengakses dan memperoses data yang disimpan dalam sebuah database komputer, diperlukan sistem manajemen database seperti MySQL Server. [9] Menurut Lestariningsih dkk, 2015, Rancang bangun merupakan kegiatan menerjemahkan hasil analisa ke dalam bentuk paket perangkat lunak kemudian menciptakan sistem tersebut ataupun memperbaiki sistem yang sudah ada. [10] Dan menurut Mulyani, 2016, UML (Unified Modeling Language) adalah "Sebuah teknik pengembangan sistem yang menggunakan bahasa grafis sebagai alat untuk pendokumentasian dan melakukan spesifikasi pada sistem”.

\section{TINJAUAN PUSTAKA}

\subsection{Tinjauan Pustaka}

[1]Penelitian pertama dari jurnal (I Putu Gede Budayasa, 2019 yang berjudul "Implementasi Sistem Informasi Pendaftaran Yudisium STMIK STIKOM Indonesia Berbasis Web”. Tujuan penelitian ini adalah mengurangi penggunaan berkas fisik sehingga memudahkan pihak program studi dalam melakukan pengarsipan dan menghindari terjadinya kecurangan berupa pemalsuan berkas. Fitur-fitur yang dibangun dalam penelitian ini mampu menunjukkan fungsionalitas sistem tersebut dapat memanajemen berkas yang ada. Hasil penelitian menunjukkan aplikasi berjalan dengan semestinya karena aplikasi dapat diarahkan ke halaman dashboard yang dimana menunjukkan status pengajuan, melengkapi data diri. Dan selanjutnya pengajuan dapat divalidasi oleh divisi yang bertanggung jawab mulai dari persyaratan akademika hingga pembayaran administrasi yudisium.

[2]Penelitian kedua dari jurnal (Mamik Umnia, 2018 yang berjudul "Rancang Bangun Aplikasi Pendaftaran Yudisium Berbasis Website di Universitas Islam Majapahit) tujuan penelitian ini adalah dapat membantu dan mempermudah proses pendaftaran yudisium, karena telah tersistem rapih mulai dari pendaftaran sampai dengan proses pengarsipan. Hasil penelitian menunjukkan aplikasi berjalan dengan semestinya akrena aplikasi dapat diarahkan dan mampu menunjukkan fungsionalitas sistem tersebut dapat menuju ke halaman menu utama berisi daftar isi atau menu-menu dari sistem Aplikasi Pendaftaran Yudisium Berbasis Website, selanjutnya ke halaman periode, kemudian ke halaman data mahasiswa lalu ke laporan peserta yudisium.

Dari penelitian yang telah dijabarkan di atas, karena terdapat beberapa permasalahan yang mempunyai kesamaan dengan penelitian yang diteliti. Walaupun demikian dalam penelitian yang peneliti lakukan terdapat beberapa perbedaan yaitu lokasi penelitian, data penelitian, metode penelitian serta perancangan sistem yang berbeda dari penelitian sebelumnya.

\subsection{Dasar Teori}

Adapun dasar teori yang mendukung dalam penelitian ini sebagai berikut: [1] Menurut Amin, 2016, Perancangan terstruktur adalah suatu pendekatan yang bekerja dari sudut pandang yang lebih tinggi menuju tingkat lebih rendah yang lebih rinci, dimana keinginan pemakai disajikan dalam diagram alir data. [2] Menurut Anhar,2010, Database adalah sekumpulan tabel-tabel yang berisi data dan merupakan kumpulan dari field atau kolom. Struktur file yang menyusun sebuah database adalah Data Record dan Field. [3] Sedangkan menurut Arief, 2011, MySQL adalah salah satu jenis database server yang sangat terkenal dan banyak digunakan untuk membangun aplikasi web yang menggunakan database sebagai sumber dan pengolahan datanya. [4] Menurut Buana, 2014, XAMPP adalah perangkat lunak open source yang diunggah secara geratis dan bisa dijalankan di semua operasi seperti windows, linux, 
solaris, dan mac. [5] Menurut Emzir, 2011, Kualitatif merupakan salah satu pendekatan yang secara primer menggunakan paradigma pengetahuan berdasarkan pandangan konstruktivisme atau pandangan partisipator atau keduanya dengan strategi pendekatan salah satunya adalah studi kasus untuk mengumpulkan data penting secara terbuka terutama dimaksudkan untuk mengembangkan tema-tema dari data. [6] Dan menurut Priyatna, 2013, Web adalah nama popular untuk world wide web (www), yakni suatu aplikasi internet yang terdiri dari perangkat lunak, kumpulan protokol, dan seperangkat aturan yang memungkinkan seseorang mengakses internet. [7] Menurut Kurniawan 2012, rancangan bangun aplikasi merupakan hasil analisa dalam bentuk perangkat lunak yang digunakan untuk menyelesaikan masalah-masalah dengan menciptakan atau memperbarui sistem menggunakan kemampuan komputer. [8] Sedangkan menurut Kustiyaningsih, 2011, Database adalah Struktur penyimpanan data untuk menambah, mengakses dan memperoses data yang disimpan dalam sebuah database komputer, diperlukan sistem manajemen database seperti MySQL Server. [9] Menurut Lestariningsih dkk, 2015, Rancang bangun merupakan kegiatan menerjemahkan hasil analisa ke dalam bentuk paket perangkat lunak kemudian menciptakan sistem tersebut ataupun memperbaiki sistem yang sudah ada. [10] Dan menurut Mulyani, 2016, UML (Unified Modeling Language) adalah "Sebuah teknik pengembangan sistem yang menggunakan bahasa grafis sebagai alat untuk pendokumentasian dan melakukan spesifikasi pada sistem".

[11] Mulyani, 2016 UML (Unified Modeling Language) adalah "Sebuah teknik pengembangan sistem yang menggunakan bahasa grafis sebagai alat untuk pendokumentasian dan melakukan spesifikasi pada sistem". [12] Mustaqbal, 2015, Pengujian perangkat lunak adalah suatu proses pelaksanaan suatu program dengan tujuan menemukan suatu kesalahan. Salah satu dari jenis pengujian yang ada adalah Alpha Test yaitu pengujian yang dilakukan terhadap aplikasi untuk memastikan bahwa aplikasi dapat berjalan dengan benar sesuai dengan kebutuhan dan tujuan yang diharapkan. Kelebihan dari pengujian alpha test dapat membantu mengidentfikasi permasalahan yang tidak ditemukan pada aktivitas sebelumnya, dapat menganalisa resiko sebelum dan sesudah produk di luncurkan. Perbaikan permasalahan diharapkan dapat mengurangi biaya pemeliharaan produk setelah rilis. [13] Nur Fatimah, 2019, Yudisium adalah proses akademik yang menyangkut penerapan nilai dan kelulusan mahasiswa dari seluruh proses akademik yang telah dijalaninya. [14] Pressman, 2012, Metode spiral merupakan suatu model proses perangkat lunak evoluisoner yang menggabungkan pendekatan prototyping yang bersifat iterative dengan aspekaspek sistematis dan terkendali yang dijumpai pada model air terjun (waterfall). [15] Rosa A.S dan Shalahuddin , 2014 Pada UML (Unified Modeling Language) memiliki diagram-diagram yang digunakan dalam pembuatan aplikasi berorintasi objek. [16] Sibero, 2013 Sibero, 2013 Hyper Text Markup Language (HTML) adalah bahasa yang digunakan pada dokumen web sebagai bahasa untuk pertukaran dokumen $w e b$.

\section{METODOLOGI PENELITIAN}

\subsection{Metode Penelitian} berikut :

Adapun metode penelitian ini adalah sebagai

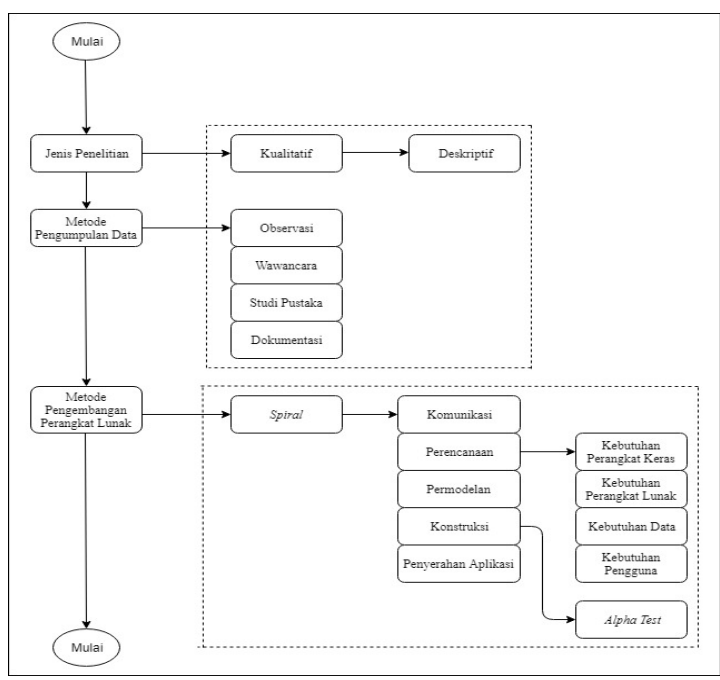

Gambar 1. Alur Metode Penelitian

\subsubsection{Jenis Penelitian}

Jenis penelitian yang digunakan oleh penulis adalah metode penelitian kualitatif yang bersifat deskriptif yang bertujuan untuk pemaparan situasi yang diteliti dan disajikan dalam bentuk uraian naratif. Pemaparan data pada umumnya menjawab pertanyaanpertanyaan mengapa dan bagaimana suatu permasalahan yang terjadi.

\subsubsection{Metode Pengumpulan Data}

Metode pengumpulan data merupakan cara-cara yang dilakukan dalam mengumpulkan data-data yang dibutuhkan dalam suatu penelitian, dalam penelitian ini metode yang digunakan oleh penulis dalam proses pengumpulan data adalah sebagai berikut :

a. Observasi 
Pada metode ini penulis melakukan survey lokasi yaitu di bagian administrasi pada Fakultas Teknik Universitas Teknologi Sumbawa untuk mengidentifikasi objek dan mengumpulkan data-data yang berhubungan dengan objek data informasi yang dibangun.

b. Wawancara

Pada metode ini wawancara dilakukan 11 Februari 2020 untuk mengumpulkan data secara langsung dengan cara melakukan tanya jawab dengan narasumber, dalam penelitian ini penulis melakukan wawancara dengan Kepala Tata Usaha di Fakultas Teknik, Bapak Hery Krisna mengenai bagaimana proses dalam pendaftaran yudisium.

c. Studi Pustaka

Merupakan metode pengumpulan data yang dilakukan dengan cara mengumpulkan data dan informasi yang relevan dengan topik atau masalah yang sedang diteliti. Informasi tersebut dapat diambil dari buku, literatur, jurnal ilmiah, testis, maupun dari internet. Dalam kasus ini, penulis mencoba untuk mencari dan mengumpulkan referensi dari buku, jurnal ilmiah maupun internet yang sesuai dengan topik penelitian sebagai bahan pendukung penelitian.

d. Dokumentasi

Dokumentasi digunakan untuk melengkapi kebutuhan dan kesempurnaan data penelitian yang dilakukan di bagian administrasi pada Fakultas Teknik Universitas Teknologi Sumbawa. Data diambil berdasarkan sumber data tambahan yang terbagi atas sumber data arsip atau dokumentasi resmi lainnya yang berada di bagian administrasi pada Fakultas Teknik Universitas Teknologi Sumbawa.

\subsubsection{Metode Pengembangan Perangkat Lunak}

Metode pengembangan perangkat lunak yang digunakan dalam penelitian ini adalah metode spiral, yaitu metode yang menggabungkan pendekatan prototyping dan waterfall yang bersifat iteratif dengan aspek-aspek sistematis serta terkendali sehingga versi pengembangan perangkat lunak yang kurang lengkap menjadi semakin lengkap.

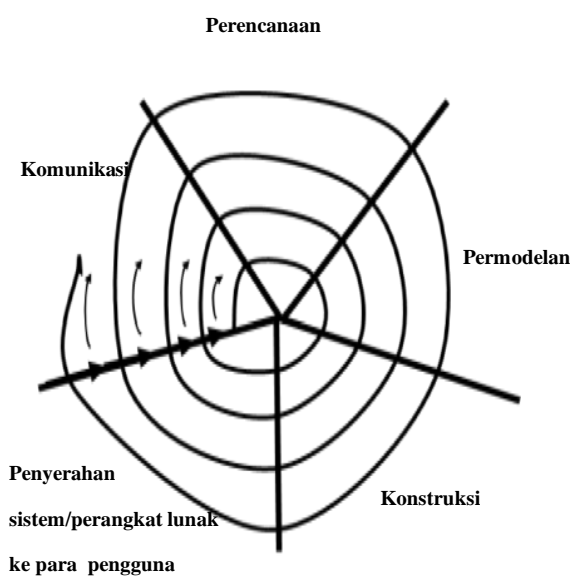

Gambar 2. Metode Spiral

Berikut adalah tahapan-tahapan dalam penelitian dengan menggunakan metode spiral sebagai metode pengembangan perangkat lunak :

a. Komunikasi

Pada tahap ini dilakukan komunikasi dengan Kepala Tata Usaha Fakultas Teknik Universitas Teknologi Sumbawa, untuk mendapatkan gambaran awal tentang aplikasi yang akan dibangun.

b. Perencanaan

Pada tahap ini dilakuan perencanaan seperti penjadwalan pada perangkat lunak yang akan di implementasikan di Rancang Bangun Aplikasi Pendaftaran Yudisium pada Fakultas Teknik Universitas Teknologi Sumbawa Berbasis Web serta melakukan analisis terhadap data dari berkas-berkas yang digunakan sebagai syarat untuk yudisium.

c. Permodelan

Pada tahapan pemodelan ini dilakukuan proses analisis terhadap rancangan yang akan dibuat, yaitu berupa gambaran umum dari Rancang Bangun Aplikasi Pendaftaran Yudisium pada Fakultas Teknik Universitas Teknologi Sumbawa Berbasis Web yang akan dibangun.

d. Konstruksi

Pada tahapan ini dilakukan pengetikan kode-kode program hingga aplikasi dapat dijalankan kemudian dilakukan proses pengujian aplikasi dengan menggunakan metode pengujian perangkat lunak Alpha Test.

e. Penyerahan Sistem / Perangkat Lunak ke Para Pengguna

Pada tahap akhir yaitu dilakukan penyerahan system/ perangkat lunak kepara pengguna. 


\section{HASIL DAN PEMBAHASAN}

\subsection{Rancangan Sistem}

Berikut ini merupakan rancangan sistem yang dilakukan dalam pembuatan Aplikasi Pendaftaran Yudisium pada Fakultas Teknik Universitas Teknologi Sumbawa Berbasis Web adalah sebagai berikut :

\subsubsection{Use Case Diagram}

Pada use case diagram dibagi menjadi 3 bagian yang digambarkan yaitu : use case diagram akun prodi, use case diagram akun mahasiswa, dan use case diagram akun admin.

a. Use case Diagram Akun Prodi

Adapun use case diagram pada akun prodi pada Aplikasi Pendaftaran Yudisium Pada Fakultas Teknik Universitas Tenologi Sumbawa Berbasis Web adalah sebagai berikut :

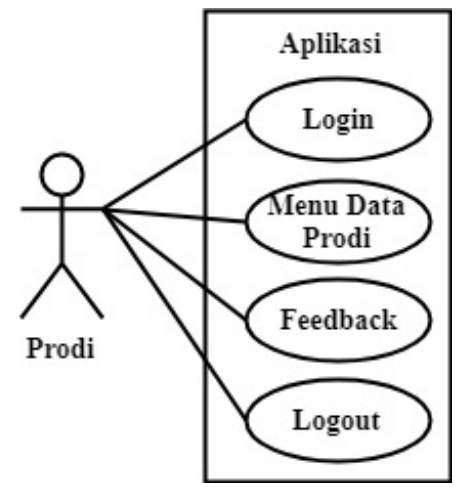

Gambar 3. Use Case Diagram Akun Prodi

Tabel 1. Keterangan Use Case Diagram Akun Prodi

\begin{tabular}{|c|l|}
\hline \multirow{2}{*}{ Aplikasi } & \multicolumn{1}{|c|}{ Fungsi } \\
\hline \multirow{2}{*}{ Login } & $\begin{array}{l}\text { User dan password didapatkan } \\
\text { dari admin fakultas untuk } \\
\text { masuk atau login ke aplikasi. }\end{array}$ \\
\hline \multirow{3}{*}{ Menu Prodi } & $\begin{array}{l}\text { Digunakan untuk mengelola } \\
\text { data mahasiswa yang akan } \\
\text { mengikuti atau dapat } \\
\text { melakukan yudisium. }\end{array}$ \\
\hline
\end{tabular}

\begin{tabular}{|c|c|}
\hline $\begin{array}{c}\text { Menu } \\
\text { Feedback }\end{array}$ & $\begin{array}{l}\text { Digunakan untuk dapat } \\
\text { mengirim feedback atau umpan } \\
\text { balik yaitu tanggapan yang } \\
\text { diberikan oleh setiap akun } \\
\text { pengguna aplikasi pendaftaran } \\
\text { yudisium. }\end{array}$ \\
\hline Logout & $\begin{array}{l}\text { Untuk keluar dari aplikasi } \\
\text { setelah selesai digunakan }\end{array}$ \\
\hline
\end{tabular}

b. Use case Diagram Akun Prodi

Adapun use case diagram akun mahasiswa pada Aplikasi Pendaftaran Yudisium Pada Fakultas Teknik Universitas Tenologi Sumbawa Berbasis $W e b$ adalah sebagai berikut :

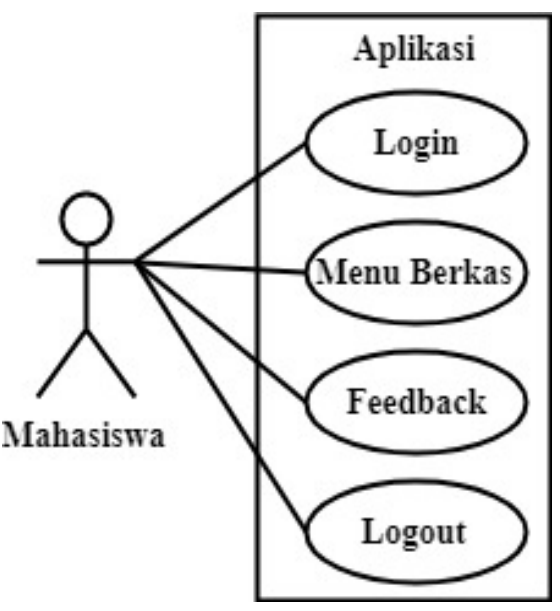

Gambar 4. Use Case Diagram Akun Mahasiswa 
Tabel 2. Keterangan Use Case Diagram Akun Mahasiswa

\begin{tabular}{|c|c|}
\hline Aplikasi & Fungsi \\
\hline Login & $\begin{array}{l}\text { User dan password didapatkan } \\
\text { dari admin fakultas setelah } \\
\text { melakukan pembayaran dan } \\
\text { digunakan untuk masuk atau } \\
\text { login ke aplikasi. }\end{array}$ \\
\hline Menu Berkas & $\begin{array}{l}\text { Digunakan untuk mengelola } \\
\text { berkas atau persyaratan yang } \\
\text { telah disediakan dan kemudian } \\
\text { di upload ke admin fakultas. }\end{array}$ \\
\hline $\begin{array}{l}\text { Menu } \\
\text { Feedback }\end{array}$ & $\begin{array}{l}\text { Digunakan untuk dapat } \\
\text { mengirim feedback atau umpan } \\
\text { balik yaitu tanggapan yang } \\
\text { diberikan oleh setiap akun } \\
\text { pengguna aplikasi pendaftaran } \\
\text { yudisium. }\end{array}$ \\
\hline Logout & $\begin{array}{l}\text { Untuk keluar dari aplikasi } \\
\text { setelah selesai digunakan. }\end{array}$ \\
\hline
\end{tabular}

c. Use case diagram Akun Admin

Adapun use case diagram akun mahasiswa pada Aplikasi Pendaftaran Yudisium Pada Fakultas Teknik Universitas Tenologi Sumbawa Berbasis Web adalah sebagai berikut :

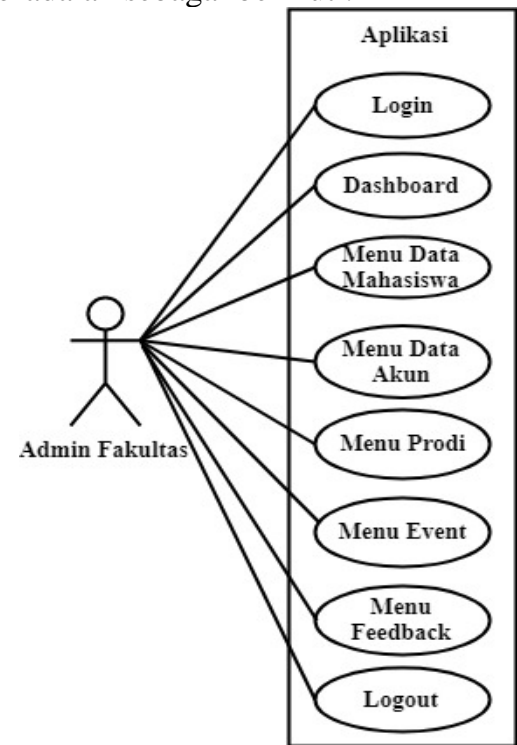

Gambar 5. Use Case Diagram Akun Admin Fakultas
Tabel 3. Keterangan Use Case Diagram Akun Admin Fakultas

\begin{tabular}{|c|c|}
\hline Aplikasi & Fungsi \\
\hline Login & $\begin{array}{l}\text { Digunakan untuk mengisi user } \\
\text { dan password serta masuk ke } \\
\text { aplikasi pendaftaran yudisium. }\end{array}$ \\
\hline Dashboard & $\begin{array}{l}\text { Digunakan untuk melihat } \\
\text { jumlah dari setiap menu yang } \\
\text { digunakan. }\end{array}$ \\
\hline $\begin{array}{l}\text { Menu Data } \\
\text { Mahasiswa }\end{array}$ & $\begin{array}{l}\text { Digunakan untuk mengecek } \\
\text { dan melakukan verifikasi } \\
\text { terhadap berkas yang telah } \\
\text { dikirimkan oleh mahasiswa. }\end{array}$ \\
\hline $\begin{array}{l}\text { Menu Data } \\
\quad \text { Akun }\end{array}$ & $\begin{array}{l}\text { Digunakan untuk membuat } \\
\text { akun dari semua pengguna } \\
\text { aplikasi. }\end{array}$ \\
\hline $\begin{array}{l}\text { Menu Data } \\
\text { Prodi }\end{array}$ & $\begin{array}{l}\text { Digunakan untuk melihat data } \\
\text { mahasiswa yang dapat } \\
\text { melakukan yudisium yang } \\
\text { telah dikirimkan oleh pihak } \\
\text { prodi. }\end{array}$ \\
\hline Menu Event & $\begin{array}{l}\text { Digunakan untuk membuat } \\
\text { setiap informasi yang akan } \\
\text { diberikan ke mahasiswa. }\end{array}$ \\
\hline $\begin{array}{l}\text { Menu } \\
\text { Feedback }\end{array}$ & $\begin{array}{l}\text { Digunakan untuk dapat } \\
\text { mengirim feedback atau } \\
\text { umpan balik yaitu tanggapan } \\
\text { yang diberikan oleh setiap } \\
\text { akun pengguna aplikasi } \\
\text { pendaftaran yudisium. }\end{array}$ \\
\hline Logout & $\begin{array}{l}\text { Untuk keluar dari aplikasi } \\
\text { setelah selesai digunakan. }\end{array}$ \\
\hline
\end{tabular}




\subsubsection{Activity Diagram}

Activity diagram bertujuan memberikan gambaran ilustrasi alur dari setiap fungsi yang ada di dalam aplikasi.

Gambar di bawah ini adalah activity diagram dari Aplikasi Pendaftaran Yudisium pada Fakultas Teknik Universitas Teknologi Sumbawa Berbasis Web yang dijabarkan sebagai berikut :

a. Activity diagram Akun Mahasiswa

Adapun activity diagram di akun mahasiswa pada Aplikasi Pendaftaran Yudisium Pada Fakultas Teknik Universitas Tenologi Sumbawa Berbasis Web adalah sebagai berikut:

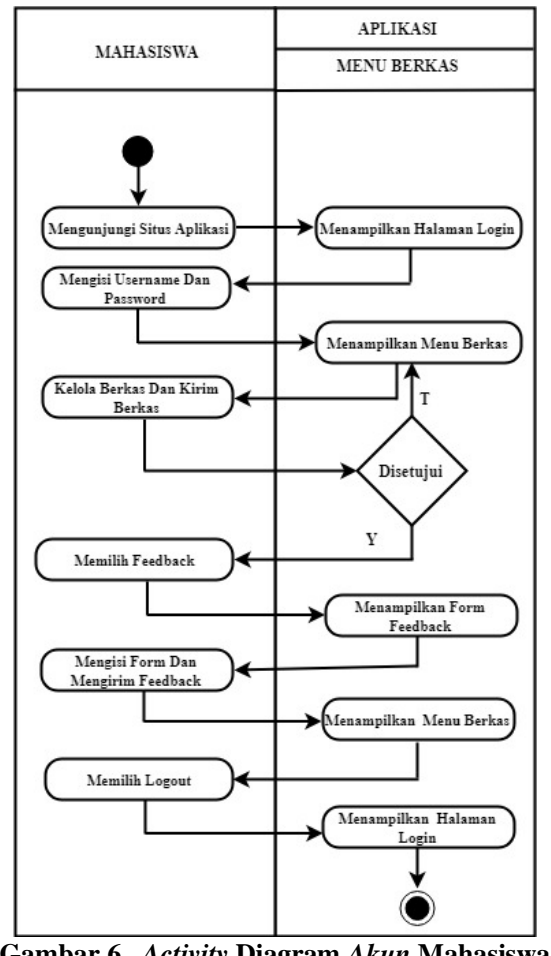

Dari gambar 4.4 menjelaskan proses yang terjadi yaitu mahasiswa mengunjungi situs aplikasi dan menampilkan menu login kemudian mengisi user dan password setelah itu aplikasi akan menampilkan ke halaman menu berkas sehingga mahasiswa tersebut dapat mengelola berkas dan mengirim berkas ke pihak admin fakultas, jika tidak disetujui maka maka akan menampilkan menu berkas dan pihak admin akan mengirimkan notifikasi ke setiap mahasiswa yang telah mengirimkan berkasnya bahwa ada kesalahan dari berkas yang dikirim, namun jika disetujui maka mahasiswa telah selesai mendaftar dan mengirim berkas yudisium. Setelah itu mahasiswa dapat memilih menu feedback maka akan menampilkan form feedback dan mahasiswa akan mengisi form dan mengirim feedback, setelah itu maka akan menampilkan menu berkas dan memilih logout dan kembali menampilkan halaman login.

b. Activity diagram Menu Data Mahasiswa

Adapun activity diagram pada menu data mahasiswa yang berada di akun admin fakultas pada Aplikasi Pendaftaran Yudisium Pada Fakultas Teknik Universitas Tenologi Sumbawa Berbasis Web adalah sebagai berikut :

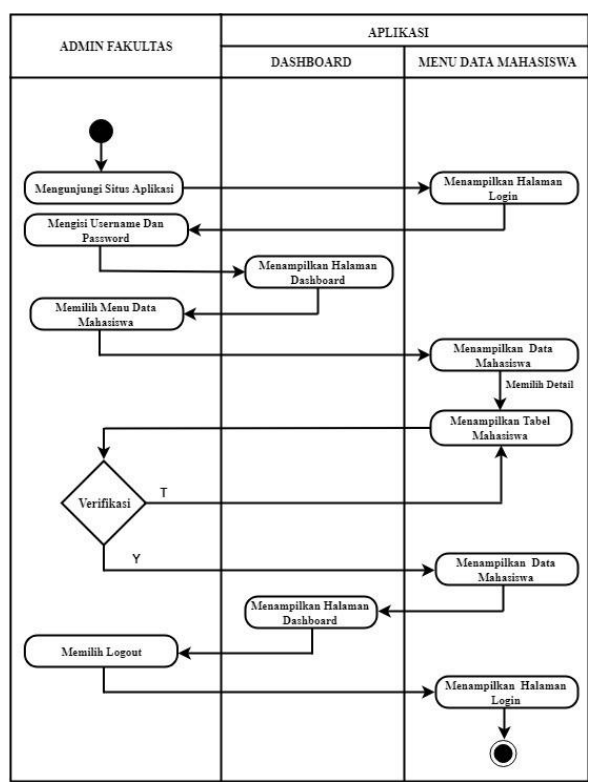

Gambar 7. Activity Diagram Menu Data Mahasiswa

Dari gambar 4.5 menjelaskan proses yang terjadi yaitu admin fakultas mengunjungi situs aplikasi dan akan menampilkan menu login dan mengisi user dan password setelah itu akan menampilkan halaman dashboard dan memilih menu data mahasiswa kemudian aplikasi dapat menampilkan tabel data mahasiswa dan memilih detail pada mahasiswa yang dituju selanjutnya pada aplikasi akan menampilkan berkas mahasiswa. Saat melakukan proses verifikasi jika tidak diterima maka akan kembali ke berkas mahasiswa, namun jika berkasnya diterima maka akan menampilkan kembali tabel data mahasiswa dan menampilkan halaman dashoard selanjutnya memilih menu logout. dan kembali menampilkan halaman login. 


\subsubsection{Sequence Diagram}

Sequence diagram adalah suatu diagram yang menggambarkan interaksi antar objek yang mengindikasikan komunikasi diantara obyek-obyek tersebut. Gambar di bawah ini adalah sequence diagram dari Aplikasi Pendaftaran Yudisium pada Fakultas Teknik Universitas Teknologi Sumbawa Berbasis Web yang dijabarkan sebagai berikut :

a. Sequence diagram Akun Mahasiswa

Adapun Sequence Diagram akun mahasiswa pada Aplikasi Pendaftaran Yudisium Pada Fakultas Teknik Universitas Tenologi Sumbawa Berbasis Web adalah sebagai berikut :

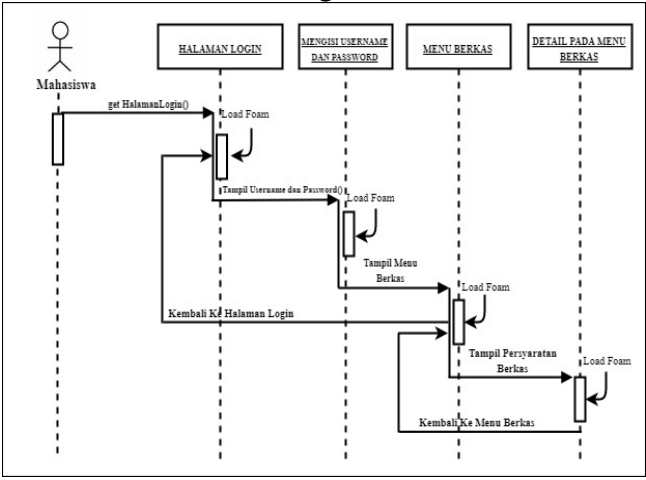

Gambar 8. Sequence Diagram Akun Mahasiswa

Pada gambar 4.6 menjelaskan sequence diagram akun mahasiswa. Proses dimulai ketika mahasiswa masuk ke halaman login dan mengisi username dan password, kemudian dilanjutkan dengan memilih menu berkas dan menampilkan detail pada menu berkas. Jika mahasiswa sudah selesai maka bisa kembali ke halaman dashboard atau dari menu prodi kembali ke halaman login.

b. Sequence diagram Menu Data Mahasiswa

Adapun Sequence Diagram Menu data mahasiswa pada Aplikasi Pendaftaran Yudisium Pada Fakultas Teknik Universitas Teknologi Sumbawa Berbasis Web adalah sebagai berikut :

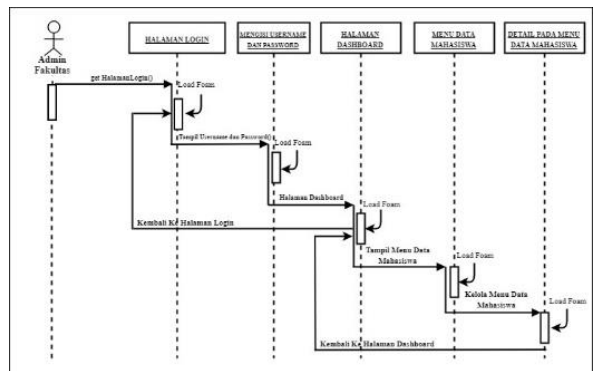

Gambar 9. Sequence Diagram Menu Data Mahasiswa
Pada gambar 4.7 menjelaskan sequence diagram menu data mahasiswa. Proses dimulai ketika mahasiswa masuk ke halaman login dan mengisi user dan password, kemudian dilanjutkan dengan menampilkan halaman dashboard dan admin fakultas dapat memilih menu data mahasiswa, kemudian aplikasi dapat menampilkan detail pada menu data mahasiswa. Jika admin fakultas sudah selesai melihat detail pada menu data mahasiswa maka dapat kembali ke halaman dashboard atau dari halaman dashboard kembali halaman login.

\subsubsection{Class Diagram}

Class diagram pada Aplikasi Pendaftaran Yudisium pada Fakultas Teknik Universitas Teknologi Sumbawa Berbasis $W e b$ ini menunjukkan interaksi antar kelas dan aplikasi serta garis yang dihubungkan antar kelas menunjukkan hubungan komunikasi antar class diagram. Gambar dibawah ini merupakan class diagram pada aplikasi adalah sebagai berikut:

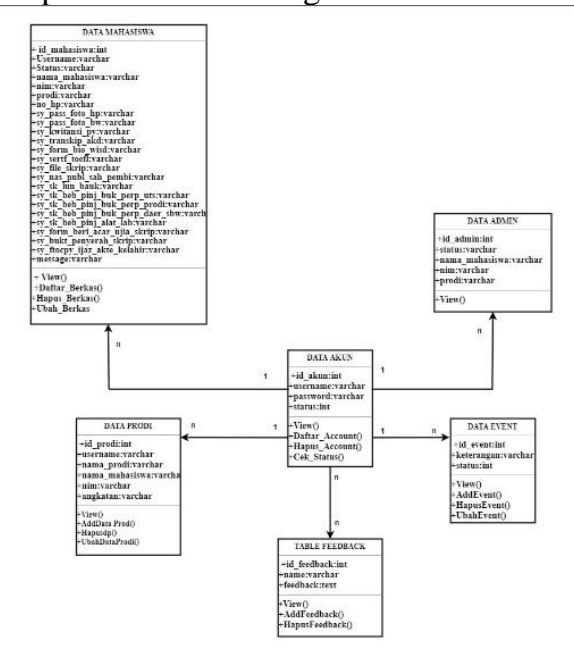

Gambar 10. Class Diagram Aplikasi Pendaftaran Yudisium pada Fakultas Teknik Universitas Teknologi Sumbawa

\subsubsection{Relasi Tabel}

Adapun relasi tabel pada basis data dari Aplikasi Pendaftaran Yudisium Pada Fakultas Teknik Universitas Teknologi Sumbawa Berbasis Web yang terdiri tabel mahasiswa, tabel user, tabel prodi, tabel event dan tabel feedback. 


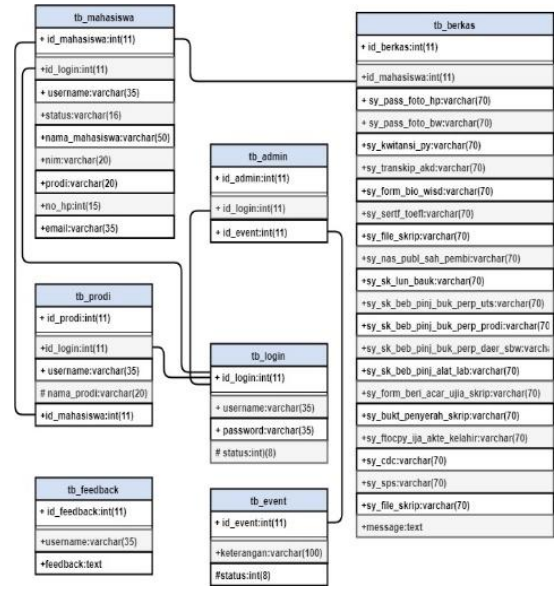

Gambar 11. Relasi Tabel Pada Aplikasi Pendaftaran Yudisium Pada Fakultas Teknik Universitas Teknologi Sumbawa Berbasis Web

\subsubsection{Rancangan User Interface}

Adapun rancangan user interface pada Aplikasi Pendaftaran Yudisium pada Fakultas Teknik Universitas Teknologi Sumbawa adalah sebagai berikut :

a. Rancangan Halaman Login

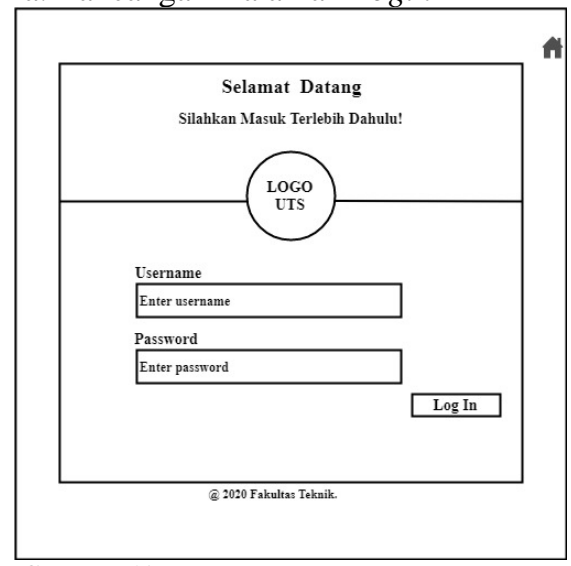

Gambar 12. Rancangan Halaman Login

Gambar di atas merupakan tampilan awal setelah user mengunjungi halaman web, dan dapat mengisi username dan password sesuai dengan akun yang diberikan.

b. Rancangan Menu Dashboard Pada Akun Admin

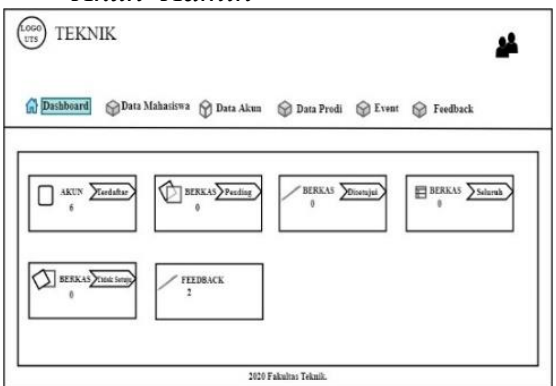

Gambar 13. Rancangan Menu Dashboard Pada Akun Admin
Gambar di atas merupakan tampilan awal di bagian admin fakultas setelah melakukan proses login.

c. Rancangan Menu Berkas pada Akun Mahasiswa

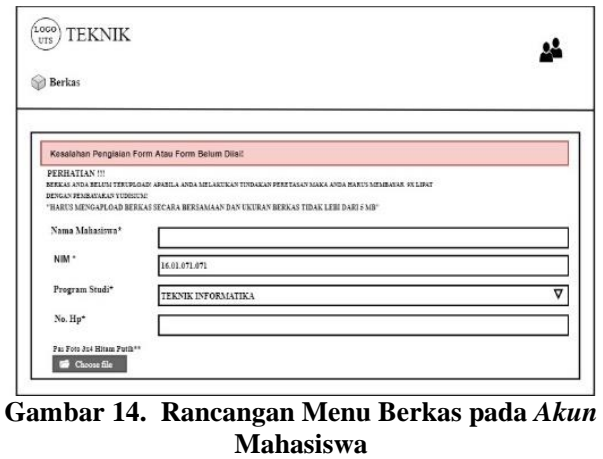

Pada gambar di atas merupakan tampilan pada saat mahasiswa melakukan proses upload terhadap berkas yang telah tersedia sebagai syarat untuk mengikuti yudisium.

\subsection{Implementasi Program}

Adapun implementasi program pada Aplikasi Pendaftaran Yudisium Pada Fakultas Teknik Universitas Teknologi Sumbawa Berbasis Web adalah sebagai berikut:

\section{a. Tampilan Halaman Login}

Adapun tampilan halaman login pada Aplikasi Pendaftaran Yudisium Pada Fakultas Teknik Universitas Teknologi Sumbawa Berbasis Web adalah sebagai berikut:

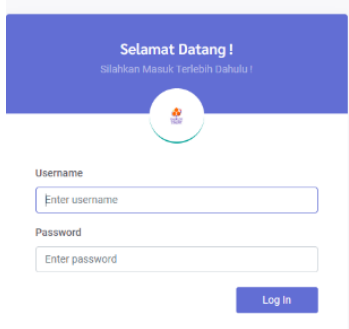

Gambar 15. Tampilan Halaman Login

b. Tampilan Halaman Dashboard Pada Akun Admin

Adapun tampilan halaman dashboard akun admin pada Aplikasi Pendaftaran Yudisium Pada Fakultas Teknik Universitas Teknologi Sumbawa Berbasis Web adalah sebagai berikut: 


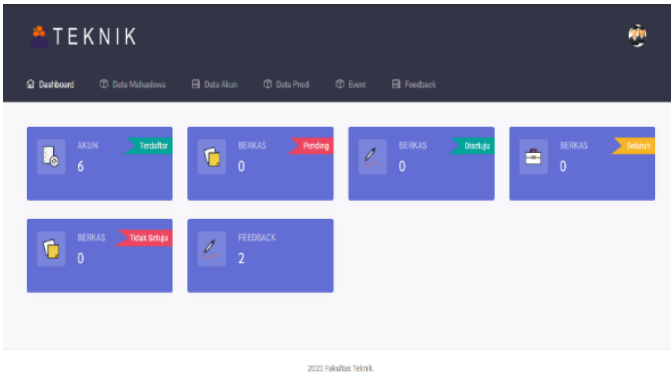

Gambar 16. Tampilan Halaman Dashboard Pada Akun Admin

c. Tampilan Menu Berkas pada Akun Mahasiswa

Adapun tampilan menu berkas akun mahasiswa pada Aplikasi Pendaftaran Yudisium Pada Fakultas Teknik Universitas Teknologi Sumbawa Berbasis Web adalah sebagai berikut:

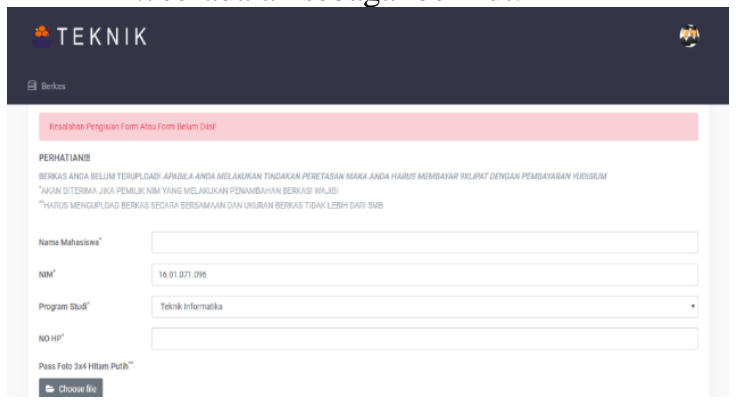

Gambar 17. Tampilan Halaman Menu Berkas pada Akun Mahasiswa

\section{PENUTUP}

\subsection{Kesimpulan}

Kesimpulan yang dapat diambil dari penelitian ini yaitu Rancang Bangun Aplikasi Pendaftaran Yudisium pada Fakultas Teknik Univrsitas Teknologi Sumbawa Berbasis Web sudah berhasil dibangun dengan menggunakan Bahasa Pemrograman PHP Database MySQL dan Text Editor Sublime Text, serta telah diuji menggunakan metode pengujian Alpha Test. Setelah dilakukan uji coba dengan multiplatform telah berhasil menjalankan seluruh proses pendaftaran yudisium dengan memberikan aplikasi yang disajikan yaitu akun prodi, akun mahasiswa, dan akun admin fakultas.menu data mahasiswa, menu data akun, menu data prodi, menu event dan menu feedback. Dengan demikian, maka penelitian ini dapat memberikan kontribusi untuk pihak prodi, pihak mahasiswa dan pihak fakultas teknik dalam proses pendaftaran yudisium pada fakultas teknik Universitas Teknologi Sumbawa.

\subsection{Saran}

Berdasarkan kesimpulan yang telah diuraikan di atas, maka saran untuk pengembangan aplikasi ini ke depannya yaitu :

1. Aplikasi dapat menyajikan fitur bukti transfer biaya yudisium.

2. Aplikasi dapat ditambahkan ruang penyimpanan data untuk dokumentasi data yudisium perangkatan.

\section{DAFTAR PUSTAKA}

1. Amin, Muhammad. (2016). "Analisis Penjualan Komputer Pada Putra Jawa Komputer Berbasis Web". Jurnal Tecnologia. Vol 7 No.4 Hal. 253.

2. Anhar. (2010)."Panduan Menguasai PHP dan MySQL Secara Otodidak". Jakarta: PT. Transmedia.

3. Arief, M.R. (2011). "Pemrograman Web Dinamis Menggunakan PHP dan MySQL”. Yogyakarta: C.V AND OFFSET.

4. Buana, I Komang Setia. (2014). "Jago Pemograman PHP”. Jakarta: Dunia Komputer.

5. Emzir. (2011). "Metodologi Penelitian Pendidikan Kuantitatif dan Kualitatif". Jakarta: PT Rajagrafindo Persada.

6. Esabella S, et al .(2020) . "Design and Build an Android-Based Digital Academic Guidebook Application at Universitas Teknologi Sumbawa". Proceeding Internatioan Conference on Science (ICST) Vol. 1 No.1 pp. 198-208.

7. Hermawan. H.K. (2020). "Penelitian Skripsi dengan Judul Rancang Bangun Aplikasi Pendaftaran Yudisium Pada Fakultas Teknik Universitas Teknologi Sumbawa Berbasis Web". Hasil Wawancara Pribadi: 28 Februari 2020, Universitas Teknologi Sumbawa.

8. Kurniawan, A. (2012). "Rekayasa Perangkat Lunak Aplikasi Penjualan Pada Toko Story Timen Factory Outlet Menggunakan Pemrogram Java". Jurnal, Universitas Andalas, hlm. 3.

9. Lestariningsih, Ardhianto \& Handoko. (2015). "Rancang Bangun E-Office Administrasi Surat Di Bagian Humas Universitas Stikubank Semarang". Jurnal Dinamika Informatika, Vol.7 No. 2, hlm. 2.

10. Lestariningsih, Endang., Ardhianto, Eka \& Handoko, W. (2015). "Rancang Bangun E-Office Administrasi Surat di Baigian Humas Universitas Stikubank Semarang". Jurnal Dinamika Informatika. Vol. 7 No. 2 hal.103.

11. Mulyani NS. (2016). "Analisis dan Perancangan Sistem Informasi Manajemen Keuangan Daerah". Notasi Pemodelan Unified Modeling Language (UML), Bandung: ABDI SISTEMATIKA.

12. Mustaqbal., Firdaus \& Rahmadi. (2015). "Pengujian Aplikasi Menggunakan Black Box Testing Boundary Value Analysis". Jurnal Ilmiah Teknologi Informasi Terapan, Vol. 1 No 3, ISSN. 2407-3911.

13. Nur.Fatimah..(((2019).."Pengertian.Yudisium.Syarat .Yudisium.Hingga.Prosesnya", (http://pelayananpublik.id, diakses 9 Maret 2020).

14. Pressman, Roger S. (2012) "Rekayasa Perangkat Lunak Pendekatan Praktisi Edisi 7". Yogyakarta: Andi Yogyakarta. 
Vol. 2 No. 4, November 2020, hlm. $238-248$

15. Rosa, A.S. \& M. Shalahuddin. (2014). "Rekayasa Perangkat Lunak Struktur dan Berorientasi Objek". Informatika: Bandung.

16. Rasefta RS and dan Shinta E. (2020). "Sistem Informasi Akademik SMK Negeri 3 Sumbawa Besar Berbasis Web". JINTEKS Vol. 2 , No.1 hlm. 50-58.

17. Sibero, Alexander F.K, dkk. (2013). "Web Programing Power Pack”. Yogyakarta : Penerbit Mediakom. 